\title{
THE FEDERAL DECLARATORY JUDGMENTS ACT
}

TT IS especially appropriate to publish in the VIRGINIA LAW 1 REVIEW the first extensive commentary on the Federal Declaratory Judgments Act. The credit for its enactment falls largely to ex-Governor, now Representative, Andrew J. Montague, of Virginia, who piloted the Act through the House of Representatives on four separate occasions. His persistence over a period of many years was finally rewarded when on June 14, 1934, President Roosevelt signed the Act ( $P$ ub. 343) giving the Federal Courts power to render such judgments. The Act reads :

\section{AN ACT}

To amend the Judicial Code by adding a new section to be numbered 274D.

"Be it enacted by the Senate and House of Representatives of the United States of America in Congress assembled, That the Judicial Code, approved March 3, 1911, is hereby amended by adding after section $274 \mathrm{C}$ thereof a new section to be numbered $274 \mathrm{D}$, as follows:

"SEC. 274D. (1) In cases of actual controversy the courts of the United States shall have power upon petition, declaration, complaint, or other appropriate pleadings to declare rights and other legal relations of any interested party petitioning for such declaration, whether or not further relief is or could be prayed, and such declaration shall have the force and eífect of a final judgment or decree and be reviewable as such.

"(2) Further relief based on a declararory judgment or decree may be granted whenever necessary or proper. The application shall be by petition to a court having jurisdiction to grant the relief. If the application be deemed sufficient, the court shall, on reasonable notice, require any adverse party, whose rights have been adjudicated by the declaration, to show cause why further relief should not be granted forthwith.

"(3) When a declaration of right or the granting of further relief based thereon shall involve the determination of issues of fact triable by a jury, such issues may be submitted to a 
jury in the form of interrogatories, with proper instructions by the court, whether a general verdict be required or not."

The Declaratory Judgments bill when introduced in the Senate on January 7, 1919,1 was confined practically to the first paragraph above, which followed closely the model of the English Order 25, Rule 5, of the Supreme Court Rules of 1883, reading:

"No action or proceeding shall be open to objection on the ground that a merely declaratory judgment is sought thereby, and the Court may make binding declarations of right whether any consequential relief is or could be claimed; or not."

The bill had been reintroduced in each Congress since 1919 and hearings upon it were held by the House Judiciary Committee on February 1, 1922, and March 25, 1926, and by a subcommittee of the Senate Judiciary Committee on April 27 and May 18, 1928. Before its final adoption in 1934 it had passed the House, after favorable report of Representative Montague speaking for the Judiciary Committee, on three separate occasions, in 1926, 1928 and 1932. The Senate Committee, after first displaying enthusiasm for the bill during the chairmanship of Senator Fletcher of Florida in 1919, permitted the initiative to pass to the House. Possibly the Senate was discouraged by the oblique dicta of the United States Supreme Court, which, like the Michigan Supreme Court at first, seemed to confuse the declaratory judgment with an advisory opinion. ${ }^{2}$ Yet the House pressed on in each session. In 1933 came the clarifying decision of the United States Supreme Court in the case of Nashville, Chattanooga and St. Louis Ry. v. Wallace, ${ }^{3}$ which in effect overruled the earlier dicta, on the generous explanation that they had been expressed on

${ }^{2} 65$ th Cong., S. 5304, and brief in support, printed by Senate Judiciary Committee, reprinted from 28 Yale Law Journal 1, 105 (Nov., Dec., 1918).

2 Liberty Warehouse Co. v. Grannis, 273 U. S. 70, 47 Sup. Ct. 282 (1927); Liberty Warehouse Co. v. Burley Tobacco Growers Coop. Marketing Asso., 276 U. S. 71, 89, 48 Sup. Ct. 291, 294 (1928) ; Willing v. Chicago Auditorium Asso., 277 U. S. 274, 48 Sup. Ct. 507 (1928). These cases are discussed at length in Borchard, Declaratory JudgMENTs, 271 et seq. (1934). The first Michigan decision on the 1919 statute, Anway v. Grand Rapids Railway Co., 211 Mich. 592, 179 N. W. 350 (1920), was in effect overruled, with the aid of an amended statute, in Washington-Detroit Theatre Co. v. Moore, 249 Mich. 673, 229 N. W. 618 (1930).

. 3288 U. S. 249,53 Sup. Ct. 345. 
the assumption that the facts in those cases were "thought" to require advisory opinions on "an uncertain or hypothetical state of facts." In the Nashoille case the Court had to determine whether it would review the final decision of a state court rendering a declaratory judgment, having in mind the fact that a negative conclusion would have made the declaratory judgments of state courts on federal questions unreviewable, thus overturning a settled constitutional rule. Facing the issue squarely and for the first time having to examine closely the nature of a declaratory judgment the Supreme Court could not but come to the conclusion that a declaratory judgment in an "adversary proceeding involving a real, not a hypothetical, controversy" meets every requirement of a justiciable "case or controversy." The Court thus reached the same conclusion as had nineteen state supreme appellate courts on the issue of constitutionality, an issue which never should legitimately have been considered debatable. ${ }^{4}$ With that obstacle disposed of, there was no longer any reason for Senate hesitation and the Senate passed the bill on June 6, 1934, the House having already on May 7, 1934, passed it (H. R. 4337) for the fourth time.

II

Had the Supreme Court in the first Liberty Warehouse case ${ }^{6}$ held, as is believed they should have, ${ }^{7}$ that the procedure for a

- The state decisions are reviewed in Borchard, supra, note 2, pp. 251 et seq.

'At the last moment, there was a threat of failure due to inadvertence. Senate 588 differed slightly from $H$. R. 4337. On June 6 the Senate, at the initiative of Senator King of Utah, chairman of the subcommittee that had dealt with the matter since 1926, unanimously passed $S$. 588 . This would have required a resubmission of the bill to the House Judiciary Committee and the House, and both houses would have had to repass the agreed bill. With adjournment so close, the bill might easily have failed. Senator King therefore on June 9 moved for reconsideration, asked for the postponement of S. 588 as passed, and substituted $H$. R. 4337, which was unanimously adopted. (Cong. Record, p. 11286.) The bill then went to the President for signature.

273 U. S. 70, 47 Sup. Ct. 282 (1927).

T This in effect seems to be admitted by the Court in the Nashville case, supra, note 3 , in these terms: "But the Constitution does not require that the case or controversy should be presented by traditional forms of procedure, invoking only traditional remedies. The judiciary clause of the Constitution defined and limited judicial power, not the particular method by which 
declaratory judgment involved matters of "practice, pleadings and forms and modes of proceeding," it would have been possible to bring actions in the federal courts for declaratory judgments at law under the Conformity Act in the thirty-four states and territories now enjoying that procedure. No federal act would have been required. In equity cases Anglo-American courts have long exercised the power to render declaratory judgments, though not expressly so denominated. The judgments of courts construing wills, interpreting deeds, trying disputed titles to property, real and personal, quieting title and declaring the non-existence of clouds, declaring the nullity of instruments and legal relations, including marriage, establishing boundaries and declaring the validity of bond issues, and judgments in an infinite variety of proceedings not requiring execution are nothing but declaratory. It is, therefore, proper to say that the statutory authorization to render declaratory judgments is merely an invitation to use a power courts have always had; so that the occasional suggestion of high judges that the federal courts had no power to render declaratory judgments indicates the psychological domination of labels and names over facts. But in view of the confusion that had been created, it was doubtless desirable to pass a special federal act, a fact which will probably persuade the remaining states no longer to forego the advantages of declaratory relief and should remove all doubts from the federal courts. Declaratory relief is neither legal nor equitable, but sui generis. It has the advantage of escaping the technicalities associated with equitable and extraordinary remedies, thus enabling the substantive goal to be reached in the speediest and most inexpensive form.

With the execution of Public 415, enacted June 19, 1934, giving the Supreme Court the power to make uniform rules in actions at law in the federal courts, ${ }^{8}$ the Conformity Act will be superseded, so that the distinction between proceedings at law and in equity will probably tend gradually to disappear and a single form of action be substituted. This should aid the utilization of the de-

that power might be invoked. It did not crystallize into changeless form the procedure of 1789 as the only possible means for presenting a case or controversy otherwise cognizable by the federal courts."

See the valuable explanation of this Act by Atty. Gen'l Cummings in United States Law Week, June 19, 1934, pp. 2, 16. 
claratory action, which differs in no respect from a traditional action except that the prayer for relief seeks only a declaration and not a coercive decree. It should help states like New Jersey finally to rid themselves of the outmoded separation of the two jurisdictions in law and equity which has resulted in social waste and injustice to the community and to litigants, barred from their goal of substantive adjudication by devious procedural obstacles. Litigants should not be turned out of courts on the excuse that they have come in through the wrong door.

The Federal Declaratory Judgments Act leaves out the reference, found in the earlier drafts, to the fact that declaratory judgments shall be rendered in cases which now or hereafter may be assigned to the federal jurisdiction. The reason for the omission is that the reference seemed unnecessary, for the Act is merely an amendment to the Judicial Code defining the federal jurisdiction, and while ostensibly conferring on the courts an additional power in cases already within their jurisdiction by reason of person and subject matter, does not add to such jurisdiction in any respect. In the customary federal cases, therefore, the courts can now render judgments which carry no execution, and while that is only a slight change, so slight that it was accomplished in England without statute and by mere rule of court, its effect is not inconsiderable. It enables the federal courts to render such judgments in two principles types of cases, (1) where all the conditions of a coercive action are present, yet where the plaintiff or petitioner is satisfied with a mild instead of a drastic remedy, merely declaring his rights; and (2) where no coercive remedy is possible, e. g., where the plaintiff seeks relief from the restrictions of a covenant or a declaration of his privilege to sublet, demolish or to act under the contract or statute free from a threatened penalty or sanction. In the former type of case, some physical "wrong" or breach may already have been committed, but the plaintiff, desiring not to sunder the economic or social relations involved, which a "fight to the finish" might entail, contents himself with a suit for a judgment declaring his rights in the premises, enabling him thus to proceed to adjust his established legal relations accordingly. The social value of this privilege of substituting adversary adjudication for embittered hostilities is evi- 
denced in the thousands of cases in England and elsewhere where this substitution of remedy has proved advantageous to all parties concerned and hence to society.

The second type of case, where no physical "wrong" has yet been committed, has three major exemplifications. There is, first, the case where each party maintains that the statute, contract or instrument under dispute means what he says it does and claims the right to act accordingly. Under traditional procedure it would be necessary, as a condition of adjudication, for one or the other party to act on his own assumption of his rights, purport to breach the contract or relation and then await a suit for damages or other coercive relief. 'Sometimes, but not usually, an injunction against breach might lie. But a party should not be bound to run such risks in order to obtain an adjudication of his rights; as was said by Mr. Justice Butler for the Supreme Court in granting an injunction against the enforcement of a criminal statute threatening property values, "they are not obliged to take the risk of prosecution, fines and imprisonment and loss of property in order to secure an adjudication of their rights." 8 Under declaratory procedure one party sues the other for a declaration that his contentions are correct or that he is privileged to act as he claims, whereupon the Court declares the "true" construction and meaning of the disputed instrument or relation. Both parties can then proceed in safety; no damage has been done; a dispute has been decided before the status quo has been ruptured, perhaps irretrievably. The saving in social waste hardly needs emphasis. Why it should have been necessary to tear down any part of the Chicago Auditorium before the lessee could obtain an adjudication of his legal privilege so to do, a privilege denied by the lessor, ${ }^{10}$ is explainable only by the narrow views of procedural tradition and the hampering restrictions of equity, which asserted that a cloud arising on the face of an instrument under construction cannot be declared. The fact that it was not possible to obtain a construction of the lease, the object of the most vital dispute between the parties, before the lessee took a possibly fatal step inviting forfeiture of the lease and a suit for waste is an indication of the defectiveness of

\footnotetext{
- Terrace v. Thompson, 263 U. S. 197, 216, 44 Sup. Ct. 15 (1923).

${ }^{10}$ Willing v. Chicago Auditorium Asso., 277 U. S. 274, 48 Sup. Ct. 507 (1928).
} 
a procedural system which does not make it previble to bring to adjudication important legal disputes without requiring violence, destruction and extraordinary risks of loss. People will often forego the exercise of rights rather than run such risks. They should not be obliged to do so. Under declaratory procedure they avoid this necessity. A contract can be construed equally effectively before a party has acted upon his own assumption as to his rights. As Congressman Gilbert expressed it in a much quoted remark in the House of Representatives on January 25, 1928:11 "Under the present law you take a step in the dark and then turn on the light to see if you stepped into a hole. Under the declaratory judgments law you turn on the light and then take the step."

In both cases the Court is a court of construction. In the one case it acts before violence has been committed, in the other, after. Violence should not be necessary; the seriousness and actuality of the dispute, the question whether the issue is real or only hypothetical, can be ascertained by the Court without requiring violence. The risks entailed are altogether disproportionate to any social advantage. No civilized system should require such a disastrous step as a condition of obtaining a judicial judgment. The decision is made, not in advance of controversy or dispute, but in advance of violence and destruction. That is the only justification for use of the phrase "advance determination," which has been occasionally employed as an adverse argument by hostile critics not fully conversant, it is feared, with the operation of declaratory procedure.

The awkwardness of the présent requirement of positive acts entailing risk and loss can be illustrated in another recent Supreme Court case. In the Piedmont Railway case, ${ }^{12}$ an electric railway company was about to build an extension of its line. The Interstate Commerce Commission, learning of this proposal, notified the Company that it was expected, as an interstate railroad under Paragraph 18 of the Interstate Commerce Act, to apply for a certificate of public necessity and convenience; otherwise, if it proceeded without certificate, it was suijjict to penalties. The Company thereupon made the application while denying the Com-

II 69 Cong. Rec. 2108 (1928).

${ }^{12}$ Piedmont \& Northern Ry: $:$. United States, 280 U. S. 469, 477, 50 Sup. Ct. 192 (1930). 
mission's jurisdiction, claiming that it was an interurban railway under Paragraph 22 and hence exempt from the requirement of a certificate. The Commission, taking jurisdiction, denied the application. In the suit to set aside the order the Railway went as far as the Supreme Court only to be told that, if the Commission had jurisdiction under Paragraph 18, the Commission's order being negative, denied no right and was not subject to judicial review; whereas if the Commission had no jurisdiction under Paragraph 22 the order was nugatory and unreviewable. The only issue was whether the Company was an interstate or an interurban railway, but that issue they could find no way to bring to judicial determination until they actually started to build the extension without a certificate, running the risks of criminal prosecution or governmental injunction and incurring heavy expense and loss of time. And that is what happened. Starting all over again they built part of the extension, were duly enjoined and were then after another expensive journey to the Supreme Court informed that they were an interstate railway and could not lay the track without permission of the Commission. ${ }^{13}$ Thus a decision, involving important public works and private and public interests, which could have been given on February 24, 1930, was delayed until May 16, 1932, with all its costs and trouble. The Company had to risk the violation of a criminal statute and submit to expensive proceedings in order to establish whether it was or was not required to obtain the certificate. This no modern legal system should require.

This type of case is closely related to the third class of typical cases for declaratory relief (the second of this special group) in which the plaintiff seeks a declaration of his privilege or immunity from the claims of some challenger of his rights. An obligor, actual or ostensible, here seeks a declaration of his immunity from the claims of a defendant or release from the demands of the obligee. This effort to escape from ostensible obligations is analogous to the equitable action for the removal of clouds from title, but extends to all legal relations. Debtors may sue creditors to establish the non-existence of the debt; covenantors sue covenantees to establish the obsolescence of the restrictions of a cove-

${ }^{18} 286$ U. S. 299, 52 Sup. Ct. 541 (1932). 
nant; lessors sue lessees to establish that they are not bound to renew the lease on its expiration as claimed, but that they are free to let to another; plaintiffs sue to establish the absence of a duty, the performance of which is demanded of them, particularly that they are released from obligations ostensibly accruing in the future; debtors may claim that they are privileged to discharge the debt in depreciated currency rather than gold; individuals may claim all types of immunity from the requirements or restrictions sought to be imposed by Governmental officials; officials may claim immunity from criminal penalty or other sanction if they act as the statute ostensibly commands, contrary to the claim or threat of a potentially injured citizen. The issues are the same whether the plaintiff or prospective defendant initiates the action and so long as danger or penalty threaten and doubt, dilemma and uncertainty menace the 'parties' freedom of action and peace of mind, there is no reason why the law should not recognize these important interests as legal and give them judicial protection against impairment. ${ }^{14}$

Somewhat similar are the actions of the fourth type (the third of this group) brought by holders of liens, mortgagees, claimants, assignees and other recipients of benefits, to establish the validity of their security or their right to receive the benefit accruing, whenever some threat or danger of its loss or impairment emanates from a defendant in a position to prejudice their rights. These actions are designed to maintain a status quc for the benefit of the plaintiff, when thrown into doubt or insecurity by claims of the defendant. They are even more common than those designed to escape peril and insecurity.

\section{III}

Coming now to the terms of the Federal Act, it may be ap-

1s A jong series of such cases, grouped by categories, is discussed in the chapters on relief from peril and insecurity. in BORChARD, supra, note 2 , pp. $30 \%$, et seq. As to the immateriality of the identity of the actor in the suit, whether norrnally plaintiff or defendant, see Fidelity National Bank \& Trust Co. v. Swope, 274 U. S. 123, 131, 47 Sup. Ct. 511, 514, where the city sued to establish the validity of its assessment, and the court said: "They (the issuis) cannot be deemed any the less so (a case or controversy) because through a modified procedure the parties are reversed and the same issues are finally determined at the behest of the city." 
propriate to explain some of the principal clauses. The opening phrase "in cases of actual controversy" owes its origin to the since overruled decision of the Michigan Supreme Court in the case of Anway v. Grand Rapid Railway Company, supra, note 2, which held the first Michigan Declaratory Judgments Act unconstitutional on the unjustified assumption that the Act required, or even permitted, the Court to render advisory opinions or decide moot cases. The majority of the Court assumed that the Michigan Act permitted it to decide cases like Muskrat v. United States, ${ }^{14 a}$ in which there were no adversary interests between the parties or a subject matter in which the plaintiff had a specific interest or which could be affected by the decision requested. Naturally, there was no federal or any other jurisdiction over such a suit, which sought an abstract advisory opinion. To foreclose the possibility of any such assumption as that into which the Michigan Court fell, the Kansas and California Acts of 1921 and the Kentucky and Virginia Acts of 1922 were supplied with the clause "in cases of actual controversy," a clause designed to make clear what should have been self-evident, namely, that only in an adversary proceeding between parties having conflicting legal interests and definitely affected by the decision, conclusively determining their legal relations, could a declaratory judgment, like any other judgment, be rendered. The unfortunate dicta of the United States Supreme Court following Liberty Warehouse Company v. Grannis, ${ }^{14 b}$ which also seemed to confuse advisory opinions with declaratory judgments-a confusion into which no other state court followed Michigan-made it seem desirable to prefix to the Federal Act the self-evident clause in question. Its purpose is to make it certain, as the Supreme Court itself announced in Nashville, Chattanooga and St. Louis Railway v. Wallace, ${ }^{15}$ that non-adversary, non-real or hypothetical issues cannot be adjudicated.

The clause "upon petition, declaration, complaint or other ap-

14a 219 U. S. 346, 31 Sup. Ct. 250 (1911).

14b 273 U. S. 70, 47 Sup. Ct. 282 (1927).

${ }^{25} 288$ U. S. 249, 53 Sup. Ct. 345 . In the Nashville case, the railway company sued for a declaratory judgment that a state tax assessed upon it was illegal, injunction against tax assessments being impossible under Tennessee law and the company not desiring, as the State insisted, to pay the tax and then sue at law for its recovery. 
propriate pleadings" was designed to furnish the widest possible form of words for the request for a judicial declaration, which may be instituted by the plaintiff or defendant, at law or in equity, in any proceeding over which, by way of parties and subject matter, the federal courts have jurisdiction. As already obzerved, the action for a declaration is neither legal nor equitable, but is sui generis, a simple request or prayer for a decision in the case declaring the rights of the plaintiff or the parties. The assumption once expressed on the floor of the House and by one of the witnesses before the House Committee that there must be an agreed statement of facts, or that both parties must concur in seeking the declaration, is quite unfounded; there need be no agreement of any kind, and in most cases it is brought against an unwilling defendant who is cited into court to have the rights of the parties declared. There is, of course, no objection to an agreed stipulation on the facts. A defendant also may seek a declaration of rights in his answer or in a counterclaim.

The term "rights and other legal relations" was designed to insure technical accuracy, by indicating that "rights" have a limited connotation and are different from duties, privileges, immunities, powers, disabilities and liabilities. The Hohfeldian analysis of jural relations has helped greatly to clarify legal thinking and has been especially useful in the application of the declaratory judgment, which seeks a declaration of a specific right or of some other legal relation or relations on the part of the petitioner. In the Uniform Act the word "status" was interpolated by the Commissioners on Uniform State Laws so that the phrase reads "rights, status and other legal relations." The interjection has disturbed the scientific unity intended by the original clause, preserved in the Federal Act, but has not interfered in its practical administration.

The clause "whether or not further relief is or could be prayed" is designed to make it clear that the declaratory judgment is an alternative remedy, and not an exceptional or exclusive or extraordinary remedy, to be employed only when no other remedy is available. Unfortunately, an occasional decision can be found in Pennsylvania, New York and Michigan, in which the court, quite by way of exception, took the view that a declaratory judgment in the instant case could not be granted because another remedy 
was available. This is not a sound or sustainable ground for refusing a declaration. If in a particular case the declaration requested would not settle the case or serve a useful purpose, it is proper, in the court's discretion, to decline it, not because another remedy is available, but because the declaration would be pointless. The terms of the Federal Act, as in the case of the Uniform Act, are intended to make it clear that the declaratory judgment can be asked in three contingencies: (1) even though a coercive decree is also sought, thus permitting a combination of prayers for a declaration plus coercive relief; $(2)$ even though a coercive decree could be but is not sought, thus enabling a petitioner to choose a milder, in place of a drastic remedy; or (3) even though a coercive decree could not have been sought, i. e., in cases where a socalled "negative" declaration of the non-existence of a duty or relief from peril or insecurity is demanded, cases in which no coercive decree is possible. The advantage of combined prayers lies in the fact that while the coercive injunction or decree of specific performance may for technical or other reasons be disallowed, the declaration may, nevertheless, be issued and effectively determine the case, ${ }^{16}$ whereas under traditional practice the denial of the injunction or decree of specific performance or damages leaves the substantive issue undecided. Thus, the statute was intended to make it very clear that the mere possibility of requesting or obtaining coercive relief is no bar to a declaratory judgment.

The prayer for declaratory relief is, in fact, not absolutely essential to obtaining a declaratory judgment. In some of the state courts, as in England, the court, having the privilege and capacity to mould its decrees to the needs of the litigants, may proprin motu, if it thinks a declaration useful or preferable to a coercive decree, grant a declaration of right, even though unasked. For example, in Hasselbring v. Koepke ${ }^{17}$ the Michigan Supreme Court was asked to enjoin the construction of a staircase on the side of a building which would, if and when the plaintiff built up to his permissible line, interfere with an easement of light which he possessed under deed. The Court found it impossible to grant an injunction under the facts, but considered it important to determine and establish the rights of the plaintiff, hence sua sponte

ss Erwin Billiard Parlor v. Buckner, 156 Tenn. 278, 300 S. W. 565 (1927).

${ }^{13} 263$ Mich. 466, 248 N. W. 869 (1933), 32 MIch. L. REv. 112. 
granted a declaratory judgment to the effect that the plaintiff had the right to the easement and that the defendant's staircase would impair it when the plaintiff built. It was an action of the fourth type above mentioned, where the plaintiff needs to insure the maintenance of the status quo against prospective impairment and prejudice by illegal acts emanating from the defendant.

The clause that "such declaration shall have the force and effect of a final judgment or decree and be reviewable as such" is designed to indicate that the declaratory judgment is a final judgment like any coercive judgment conclusively determining the rights of the parties and constituting res judicata. State declaratory judgments are of the same character, a fact recognized by the United States Supreme Court in reviewing the Tennessee decision in the Nashoille case. The declaratory judgments of federal courts are equally final and reviewable.

The second and third paragraphs of the Federal Act were added out of an abundance of caution, for in England the requirements of both paragraphs are achieved by customary practice or rule of court. The second paragraph of the new Act providing that "Further relief based on a declaratory judgment * * * may be granted whenever necessary or proper" is intended to afford a successful petitioner for a declaration an opportunity to have the judgment carried into coercive effect in the event that a recalcitrant losing party declines to respect it. In practice it has rarely, if ever, been necessary to invoke the ancillary aid of a coercive decree to compel enforcement of a declaratory judgment, for the refusing party can only lose; but if perchance it should prove necessary to coerce, it is easy to apply to the court, on citation of the adverse party, for further and summary relief based on the judgment.

The third paragraph, providing for the submission of questions of fact to a jury on interrogatories, is designed to safeguard constitutional guaranties in this respect and to simplify the finding of facts, should that prove essential in any case. There are, perhaps, several reasons why such provisions have rarely been invoked either in England or the United States: (1) because issues depending on complicated facts requiring the taking of extensive testimony are not usually brought for declaratory relief and are not the most adaptable to that form of relief; (2) because most 
of the cases are usually tried as in equity where the judge finds the facts; and (3) because in a suit for declaratory relief on the law side a jury is generally waived. But if a question arises in the course of a trial, or if the parties stipulate or the court concludes that certain issues in a declaratory suit require submission to a jury the way is left open for that form of finding by interrogatories, the answers to which the court will take into account in rendering the declaratory judgment on the law.

Some of the earlier drafts of the federal bill had a fourth paragraph providing that the court may make rules to carry the Act into effect, but this was dropped from later versions because it was felt that the existing rules of practice would be followed in declaratory actions, the only difference involving the prayer for relief, which asks for a declaration, with or without a coercive decree. If the Supreme Court should take advantage of its now complete rule-making power to include rules on declaratory judgments, it may follow the New York and Connecticut example of incorporating into the Rules the results of judicial precedents in the use of the declaration, an experience which in general terms was incorporated in the comprehensive Uniform Act because so many states do not yet confer on their courts adequate rule-making power. The Supreme Court of the United States, like the Supreme Court of Judicature in England, would have been empowered to adopt and make rules for declaratory judgments without any authorizing statute, but in the light of experience it was deemed preferable to have the guidance of an Act of Congress.

\section{IV}

For the rest, the federal courts will doubtless follow the general law and practice of declaratory judgments as developed in England since 1883 and in the United States since 1919. There is no limitation on the subject-matter or type of issue that may be adjudicated by declaration; it may involve the construction of written instruments or arise independently of such instruments. It is, of course, essential that the federal jurisdiction extend to the suit. It is necessary that the parties have a definite and adverse legal interest which will be conclusively affected and determined by the judgment. All the elements of a litigation must be present; only the prayer for relief is different. 
Issuance of the declaration, it is commonly said, is discretionary with the Court, but this does not imply arbitrariness or caprice, but discretion according to rule and to criteria established by precedent, namely, whether the judgment will serve a useful purpose and whether it will finsly settle the litigation. If it does, the declaration must generally be issued, the discretion of trial courts being reviewable on appeal. When issued, the declaratory action will be found to have been simpler, more inexpensive and much speedier than an ordinary action. So effective in this respect have several states found the declaratory action that the code provides that actions for declaratory judgments shall be given preference on the calendar. Inasmuch as the issue submitted in a suit for a declaration is usually a narrow one, on which larger issues often depend, it has been found expedient and useful to afford encouragement to declaratory actions, which permit parties to avoid the accumulation of bitterness and personal hostility which prolonged coercive litigation usually carries in its train.

The greatest usefulness of the declaratory judgment in the federal jurisdiction will probably lie in the field of constitutional and administrative law, in the testing of the statutory and administrative powers of officials under federal and state legislation, in so far as original federal jurisdiction still extends to such control over state action. It will probably to some extent supersede the injunction, which has often been abused to permit an adjudication on the validity of a law or administrative order. In that respect it will be helpful, both in confining the injunction to its legitimate uses and overcoming the growing hostility to that form of restraint on public action, and in bringing to speedy adjudication contested issues between the citizen and the administration. Probably we shall now hear less of suits for injunction before a statutory three-judge court under section 266 of the Judicial Code, for a declaratory action before a single judge will usually serve equally effectively. In most cases what is wanted by litigants is an adjudication on the law, for which the injunction is merely a procedural vehicle and unnecessary appendage; officers will generally obey the law when it is judicially and authoritatively declared and require little coercion, because refusal to heed the declared law would be fruitless and costly. But if in a particular case it seems necessary to tie the hands of officers pending 
adjudication, injunction can still be requested, either alone or in combination with a declaration. As already observed, it is well to request both, for the declaration may often be granted when on technical grounds the injunction may be refused.

The declaration is also likely to be used in those civil cases in which the parties can bring themselves within the jurisdiction of the federal courts, either by special statute or on the ground of diversity of citizenship. The difficulty of determining whether $\$ 3,000$ is involved will be no greater than it now is. The declaration has proved especially valuable in the construction of written instruments, notably contracts of all kinds, including leases, deeds, assignments, mortgages, insurance policies, corporation and partnership agreements, and in issues involving titles to property and status, including citizenship. The construction of wills and trusts directly, a common matter for declaratory adjudication in the states, will hardly be of great importance in the federal courts. But the ever wider range of federal legislation and hence of federal jurisdiction affords a growing field for the pacific ministrations of the declaratory judgment. There is no reason to doubt that it will prove as efficacious in settling disputes and in avoiding peril and insecurity in the federal courts as it has proved in the state courts and in foreign countries. Its career as a reformer of federal procedure will be watched with interest.

YATE LAW ScHOOL.

Edwin Borchand.

NEW Haven, Cons. 